\title{
Italy's fascist past: A difficult reckoning
}

In a survey conducted in 2002 for a well-known television programme Michele Santoro's Sciuscià - a sample of young Italians were asked for their views on fascism. From the sample, $71 \%$ of those interviewed expressed a negative judgement, $24 \%$ a positive judgement and $5 \%$ did not know. A similar result was obtained when the same question was asked about Mussolini. 73\% expressed a negative judgement, $25 \%$ a positive judgement and $2 \%$ did not know. But when asked about Hitler, $96 \%$ of interviewees gave a negative judgement, $3 \%$ a positive one and $1 \%$ did not know. ${ }^{1}$

The results of the survey highlighted a macroscopic difference between young Italians' view of Hitler (and presumably of national socialism) and their judgement of Italian fascism and "il Duce": at least one in four young Italians had a positive view of fascism and Mussolini, while only a negligible minority felt the same way about the Führer.

The survey is not recent, and should be treated with caution because its scientific criteria were not indicated. It did however offer a snapshot of a real underlying situation that does not seem to have changed since then. That is, it revealed that Italy had not yet critically worked through its own fascist past, to the extent that among young Italians there was quite a widespread positive view of fascism, clearly distinct from the cruel and rightly execrated one of German Nazism.

The attitude of these young Italians should not come as too much of a surprise. In fact, a distinction between the two main historic fascisms, the Italian one and the German one, has been presented insistently by the Italian mass media for many years, with fascism mainly portrayed as a bland authoritarianism radically different from the brutal and bloody Nazi regime.

1 See F. Focardi, "Il vizio del confronto. L'immagine del fascismo e del nazismo in Italia e la difficoltà di fare i conti con il proprio passato", [in:] Italia e Germania 1945-2000. La costruzione dell'Europa, eds. G.E. Rusconi, H. Woller, Bologna 2005, pp. 91-121, here p. 120. 
But where does this benevolent memory of fascism, still widespread in broad sectors of Italian society, and not just among the young, originate? My thesis is that it is intrinsically correlated to the demoniacal image of Nazism, and that this correlation dates back to the Second World War, to the way in which the experience of the fascist regime and of the conflict was worked through in the immediate post-war period.

We know that major armed conflicts lead to a recasting of the world order. ${ }^{2}$ But they also have a no less significant cultural impact. For example, wars modify and structure the perception and representation that peoples have of themselves. Often the self-image constructed by a people is defined by way of contrast with that of another people. In my view, this applies very well to the relationship between the Italians and Germans after the war. The myth of the "good Italian", a person who was against the war and championed humanitarianism, was for example constructed after 1945 in contrast to the image of the "wicked German", a fanatical soldier capable of any crime. ${ }^{3}$ The same holds true for the opposition between fascism and Nazism. It arose from the depiction of the two regimes that was shaped in the immediate post-war period both by anti-fascist culture and by the culture that we might define as post-fascist or anti-antifascist.

The first clear-cut distinction between fascism and Nazism was drawn by the anti-fascist side. All the anti-fascist parties, from the liberals to the communists, who were jointly in charge of the country from April 1944 to May 1947, were united by the political imperative to ensure Italy obtained a non-punitive peace. Italy had fought alongside Nazi Germany for over three years, had been invaded and forced to surrender. Despite the subsequent co-belligerence alongside the Allies, and despite the Resistance, Italy was a defeated enemy nation. It was this condition that determined the need felt by the new anti-fascist ruling orders to protect the fortunes of the country, avoiding the threat of a "Carthaginian peace" like the one that the Allies had already indicated they wished to impose on Germany. ${ }^{4}$ The various anti-fascist forces therefore shared a common desire to separate the fortunes of the country from those of Hitler's Germany. They likewise wished to distinguish Italian responsibilities from German ones for the war fought together by the Axis Powers against the Allies from June 1940 to September 1943. Hence there is the tendency to stress differences when comparing the Italian and the German experiences, both as regards the nature of the two regimes and the behaviour of the Italians and Germans during the conflict. Obviously, there had been very significant differences between the two fascist dictatorships in Italy and Germany. The same

2 See, for example, L. Bonanate, F. Armao, \& F. Tuccari, Le relazioni internazionali. Cinque secoli di storia: 1521-1989, Milano 1997, pp. 1-24.

3 I have analysed the construction of these intertwined images - the "good Italian" and the "wicked German" - in my last book Il cattivo tedesco e il bravo italiano. La rimozione delle colpe della seconda guerra mondiale, Bari-Roma 2013.

4 See ibid., pp. 52-76. 
can be said of the conduct of the two nations during the war. Italian crimes had been far less serious than German ones, ${ }^{5}$ and Italy itself had been a victim of Nazi violence. ${ }^{6}$ From this point of view, anti-fascist voices did nothing other than express a politically legitimate and historically founded judgement. However, the crucial political imperative to safeguard the destiny of the nation led to an accentuation of the elements differentiating fascism and Nazism rather than of the factors common to the two dictatorships.

An initial sphere of reflection concerned the origins of Fascism and Nazism. Here the most authoritative voice was that of the liberal philosopher Benedetto Croce, the most prestigious Italian intellectual of the time. According to Croce, Fascism was a passing moral illness, a brief parenthesis in a long Italian history distinguished by Latin civilization, Renaissance humanism and the liberal Risorgimento. By contrast, Nazism was part of a hereditary disease for Germany, the outpouring of a thousand-year-long history that began with the defeat of the Romans in the forest of Teutoburg in $9 \mathrm{CE}$; a history characterised by the lack of a sense of freedom, by the cult of force and unconditioned obedience to authority. $^{7}$ It was precisely this different historical-cultural background that explained, according to Croce, the differing criminal propensity of the two regimes, which was much more marked and devastating in the case of Nazism. ${ }^{8}$

It is important to stress that Croce did not make these reflections from an intellectual ivory tower but in the political arena, when asking the Allied authorities not to punish Italy for the lost war. In his view, in fact, the "Italy of the communes

5 Unlike the Germans, the Italian military forces were not stained with genocidal mass crimes. However, in the occupied territories, especially in the Balkans (in Yugoslavia, Albania, Greece), they committed serious war crimes against civilians and partisans (village destructions, reprisals, massacres, hostage killings, deportations of men, women and children to concentration camps). At the end of the war over a thousand Italians, including soldiers and members of the Fascist administration, were enrolled as war criminals on the lists of the United Nations War Crimes Commission. Nobody was handed over and put on trial. See D. Conti, Criminali di guerra italiani. Accuse, processi e impunità nel secondo dopoguerra, Roma 2011; F. Focardi, "Italy as occupier in the Balkans: Remembrance and war crimes after 1945", [in:] Experience and Memory. The Second World War, eds. J. Echternkamp, S. Martens, New York-Oxford 2010, pp. 135-146.

${ }^{6}$ During the German occupation of Italy (8 September 1943-2 May 1945) over 20,000 civilians were victims of Nazi violence. More than 40,000 Italian soldiers died in German concentration camps, about 8,000 Italian Jews were deported and exterminated, and more than 10,000 Italian antifascists died in the German lagers. See: G. Fulvetti, \& P. Pezzino, Zone di guerra, geografie di sangue. L'Atlante delle stragi naziste e fasciste in Italia (1943-1945), Bologna 2016; L.P. Fargion, Il libro della memoria. Gli ebrei deportati dall'Italia (1943-1945), Milano 2002; Il libro dei deportati, vol. 1, [in:] I deportati politici 1943-1945, eds. G. D’Amico, G. Villari, \& F. Cassata, Milano 2009.

7 See B. Croce, Il dissidio spirituale della Germania con l'Europa, Bari 1944 (now in: idem, Scritti e discorsi politici 1943-1947, vol. 1, Bari 1963, pp. 145-165).

${ }^{8}$ For an acute analysis on Croce's comparative reflection on Italian fascism and German Nazism see: G. Galasso, "Benedetto Croce e l'unità europea", Nuova Storia Contemporanea 5, 1998, pp. 15-44, here p. 38. 
and Cavour" could not be placed on the same plane as the "Germany of Bismarck, Wilhelm II and Hitler".9

This reading, which highlighted the different historic origins of Fascism and Nazism, was shared by Catholic culture. ${ }^{10}$ According to the latter, Fascism had not expressed its totalitarian and criminal potential in Italy because it had been thwarted by a healthy ethical and cultural fabric strengthened by the Christian-Catholic tradition. Fascism had been, as the philosopher Jacques Maritain stated, "a totalitarianism held in check by Catholicism". ${ }^{11}$ By contrast, Nazism had taken root in a country which, since Luther's reformation, had taken a divergent path culminating in the barbarities of the "racist neo-paganism" of Hitler's regime. ${ }^{12}$

A converging point of view was also expressed by Marxist culture. ${ }^{13}$ Admittedly, it interpreted Fascism and Nazism in a completely different way from Croce and the Catholics: as the product of the class reaction of financial and industrial capitalism in cahoots with the big landowners. But yet Marxist culture highlighted the differences between Fascist Italy and Nazi Germany. In Italy there had been nothing like the antidemocratic tradition that existed in Germany. ${ }^{14}$ Marxist culture was also of the view that antibodies had remained active in Italy, thwarting Fascism. On this point, the leader of the Communist Party, Palmiro Togliatti, was in agreement with the liberal Croce. According to Togliatti, Fascism had not succeeded in penetrating "into the core of the popular spirit" in Italy, because it had run up against "deep traditions associated with the whole development of Italian civilisation": "the civilisation of Rome", "Catholic culture", the Renaissance, the Risorgimento and finally, he added, the traditions of the workers' movement. ${ }^{15}$

Antifascist culture also concurred with the idea that Fascism had not had its own ideology. It discredited and mocked Fascist nationalism, the vacuous and superficially pompous "Romaness"; it discredited corporatism as bogus, attacking, that is, the representation Fascism wanted to give of itself. By contrast, it accepted

9 See B. Croce, "La libertà italiana nella libertà del mondo", [in:] idem, Scritti e discorsi politici 1943-1947, vol. 1, pp. 49-58.

10 F. Focardi, "Il vizio del confronto...", pp. 95-97; A. Giovagnoli, La cultura democristiana, Roma-Bari 1991, p. XIV.

11 J. Maritain, Umanesimo integrale, Roma 1949, p. 221. The original edition of the work was published in France in 1936. Maritain, who from 1945 to 1948 served as French ambassador to the Vatican, exerted profound influence on Italian Catholicism.

${ }^{12}$ For the definition of Nazism as Neopaganism see the influential volume of the Catholic historian Mario Bendiscioli, Neopaganesimo razzista, Brescia 1945 (first edition 1937). On Bendiscioli's reflection on Nazism and Fascism is now available the volume of Francesco Torchiani, Mario Bendiscioli e la cultura cattolica fra le due guerre, Brescia 2016.

13 See F. Focardi, "Il vizio del confronto...", pp. 97-98.

14 See for example the review written by the philosopher Cesare Luporini to the book Gregor Ziemer, Educazione alla morte. Come si crea un nazista, Londra 1944 published in Società 3, 1945, pp. 283-286.

15 See P. Togliatti, "L'Italia e la guerra contro la Germania hitleriana”, [in:] idem, Opere, eds. F. Andreucci, P. Spriano, IV/2, Roma 1979, pp. 378-379. 
the self-depiction of Nazism as a compact Volksgemeinschaft united by a racist and anti-Semitic ideology. The Italians were described as being, at heart, unresponsive to Fascism, just paying lip service to it out of a need to "make ends meet". The Germans, on the other hand, were described as convinced and fanatical supporters of Nazism and its Führer. As both Croce and the communist intellectual Ranuccio Bianchi Bandinelli observed, the Italians "played the part" of Fascists, the Germans "were" Nazis. ${ }^{16}$

A key discriminant was identified in anti-Semitism. The introduction of the racial laws in Italy in 1938 was judged at the time by the whole of antifascist culture as a measure imposed by Hitler's Germany, against the wishes of the Italian people, who demonstrated their true feelings in the help they gave to their persecuted Jewish fellow citizens. ${ }^{17}$ Today we know that actually Germany did not intervene directly to get anti-Semitic legislation introduced in Italy (indeed, in the educational sector, Italian laws preceded German ones). ${ }^{18}$ We know all about the pervasiveness and persecutory efficacy of such legislation, which excluded Italian Jews from civil society, even though it did not lead to their elimination, as in Germany. ${ }^{19}$

The difference between the Fascist and Nazi regimes was also explained by antifascist culture in terms of the different character of the two peoples. ${ }^{20}$ It was argued, for example, that Fascism came to power by exploiting certain negative characteristics of the Italians, such as an exclusive interest in their own "particular" concerns, opportunism and a lack of respect for the law. At the same time, however, those same characteristics had put a brake on the totalitarian drive of Fascism. By contrast, in Germany the Nazis had been able to exploit not only the negative qualities of the Germans (blind discipline, a warlike spirit), but also their positive qualities (abnegation, sense of order, respect for the law, organisational skills), creating a compact and aggressive totalitarian regime, without equal in Italy.

Finally, the two leaders, Mussolini and Hitler, were portrayed differently. ${ }^{21}$ Antifascist culture as a whole subscribed entirely to a demoniacal depiction of Hitler as the reincarnation of the anti-Christ, bloodthirsty, crazy and ruthless, while Mussolini was described as a vain, hammy actor, a weak-kneed Caesar. Efforts

16 See respectively B. Croce, Il dissidio spirituale..., pp. 21-22; and R.B. Bandinelli, Dal diario di un borghese e altri scritti, Milano 1948, p. 70.

17 See F. Focardi, "Alle origini di una grande rimozione. La questione dell'antisemitismo fascista nell'Italia dell'immediato dopoguerra", Horizonte. Italienische Zeitschrift für Kulturwissenschaft und Gegenwartsliteratur 4, 1999, pp. 135-170. We recall that the Italian Jewish community itself in the early postwar years emphasized the humanitarian merits of Italian society and discharged all responsibility for anti-Semitic persecution on the Germans' shoulders. See G. Schwarz, Ritrovare se stessi. Gli ebrei nell'Italia postfascista, Roma-Bari, 2004.

18 See E. Collotti, Il fascismo e gli ebrei. Le leggi razziali in Italia, Roma-Bari 2003.

19 See M. Sarfatti, Gli ebrei nell'Italia fascista. Vicende, identità, persecuzione, Torino 2000.

20 See F. Focardi, Il fascismo e la guerra dell'Asse. Una mancata resa dei conti, Padova 2013, pp. 182-197.

${ }^{21}$ See F. Focardi, “Il vizio del confronto...”, pp. 98-100. 
were therefore made to make fun of and deflate the figure of the "Duce", who not long before had been revered by many Italians. By doing so, however, a misleading anti-myth was created that failed to acknowledge the historic figure of Mussolini as the head of a modern totalitarian dictatorship. ${ }^{22}$

As mentioned, the contrast between Fascism and Nazism was shared by post-fascist culture as well. It expressed the mood of broad sectors of Italian society, especially of the lower-middle and middle classes, hostile to anti-fascism and still infused with nationalist sentiment. A significant part of Italian society had adhered to and believed in Fascism, distancing themselves from it late on and attributing to Mussolini the error of the alliance with Germany that had led to war and defeat. The leading voice of the cultural orientation we are speaking of was without doubt Indro Montanelli, probably the most widely read journalist in post-war Italy. ${ }^{23}$ From his first book on Fascism, Il buonuomo Mussolini, written in 1947, ${ }^{24}$ till his death in 2001, Montanelli recounted a romanticised history of Fascism, described as a bland regime, a benign and paternalistic authoritarianism, not without some presumed merits such as the reestablishment of order after the Great War, or the modernisation of the country, finally equipped with trains that "ran on time" and with its marshes reclaimed.

In describing Fascism, Montanelli resorted widely to the comparison with Nazism as well. He played down Fascist anti-Semitism, depicting it as a pale imitation of the frenzied German version. He opposed the figure of Mussolini, a vain, rhetorical leader, to that of the cruel, bloodthirsty Führer. Two profiles to which there corresponded, in his view, two quite different regimes: a demagogic, airy-fairy Fascist regime, and a barbarous, totalitarian Nazi one.

This view of Mussolini and Fascism has also interacted to a considerable extent with the morbid curiosity shown by the mass media (illustrated magazines, cinema and then television) from the end of the 1940s till today in Mussolini's private affairs - his relationship with his wife, his children, his lover Claretta Petacci, with his son-in-law Galeazzo Ciano - in an unbroken flow of revelations and gossipy conjecture of often dubious reliability. This has in any case produced a genuine "banalisation of Mussolini in an intimate-family sense". ${ }^{25}$ Everything has contributed to creating what the historian Cristina Baldassini has called an "indulgent memory", a representation of Fascism as a regime which, all in all, "had a human face", not as repugnant as Nazism. ${ }^{26}$ This helped to soothe or prevent the sense of guilt of many Italians who had been Fascists.

22 See A. Campi, Mussolini, Bologna 2001.

23 See S. Gerbi, R. Liucci, Indro Montanelli: una biografia (1909-2001), Milano 2014.

24 Sergio Luzzatto drew attention on the importance of this Montanelli's book. See idem, Il corpo del duce, Torino 1998, pp. 122-125.

25 See S. Luzzatto, op. cit., p. 228; A. Campi, op. cit., pp. 42-48.

26 See C. Baldassini, L'ombra di Mussolini. L'Italia moderata e la memoria del fascismo (1945-1960), Soveria Mannelli 2008. 
To summarise, in the immediate post-war period in Italy we can see a fundamental element of convergence between the antifascist and the post-fascist reading of Fascism. They were without question animated by different reasons, and continued to be divided on fundamental issues such as that of consensus for the regime, to which we will return shortly. The two readings did share however what we can describe as a flaw of comparison: the habit, that is, to define and judge Fascism against the yardstick of Nazism. A flaw which has inevitably favoured the spread of a sweetened image of the Fascist regime.

In historiography, the interpretation of Fascism given from the second half of the 1960s by Renzo De Felice lay within this furrow. ${ }^{27}$ In fact, the most authoritative and influential Italian historian of Fascism proposed an interpretation based on comparison between Fascism and Nazism, emphasising the differences between them to the point of considering them to be historical phenomena of a quite different nature. ${ }^{28}$ De Felice distinguished clearly between Nazi anti-Semitism and Fascist anti-Semitism, placed Italy "outside the cone of shadow of the Holocaust"29 (without taking account of the anti-Semitic actions of the Republic of Salò), played down the role of fascist violence inside and outside the country, stressed the limits of the fascist regime's totalitarian project compared to the Third Reich, considering Fascism as, at most, an "imperfect totalitarianism". ${ }^{30}$

In the years of the so-called Second Cold War, between the end of the 1970s and the first half of the 1980s, De Felice became the point of reference of Italian revisionism, which moved along two connected tracks: criticism of the Resistance as a phenomenon hegemonised by the communists, and the re-reading of Fascism as a mild authoritarianism capable of promoting the modernisation of the country and of mobilising a vast mass consensus. ${ }^{31}$ Giving voice to this strand of revisionism were an array of journalists and history writers, from Arrigo Petacco to Antonio Spinosa, Roberto Gervaso to Giordano Bruno Guerri, with Montanelli, as we said, to the fore. The function of these prolific writers, exhibition curators

27 Renzo De Felice's main work on Fascism is represented by the eight toms of his biography on Mussolini issued between 1965 and 1997. Very important is also his book dedicated to fascist anti-Semitism: Storia degli ebrei italiani sotto il fascismo, Torino 1961. On De Felice see the volume of one of his most important pupils: E. Gentile, Renzo De Felice: lo storico e il personaggio, Roma-Bari 2003.

28 See G. Santomassimo, "Il ruolo di Renzo De Felice", [in:] Fascismo e antifascismo. Rimozioni, revisioni, negazioni, ed. E. Collotti, Roma-Bari 2000, pp. 415-429.

29 In the famous interview given to Giuliano Ferrara for the principal Italian newspaper $\mathrm{ll}$ Corriere della Sera (27.12.1987). The text of the interview in: F. Focardi, La guerra della memoria. La Resistenza nel dibattito politico italiano dal 1945 a oggi, Roma-Bari 2005, pp. 252-254.

${ }^{30}$ However, as Emilio Gentile noted, Renzo De Felice, too, since 1988 had fully recognised the totalitarian character of Fascism. See E. Gentile, La via italiana al totalitarismo. Il partito e lo Stato nel regime fascista, Roma 2008 (first edition 1995), pp. 307-308.

31 See F. Focardi, "Il passato conteso. Transizione politica e guerra della memoria in Italia dalla crisi della prima Repubblica ad oggi”, [in:] L'Europa e le sue memorie. Politiche e culture del ricordo dopo il 1989, eds. F. Focardi, B. Groppo, Roma 2013, pp. 56-59. 
and TV programme consultants was to articulate De Felice's vision of Fascism for the general public, to the point of creating a genuine media vulgate that tended to simplify and radicalize De Felice's theses. This vulgate placed the figure of Mussolini at the centre of the regime's history. An "arch-Italian" Mussolini, the embodiment of the virtues and vices of his people, and as such capable of forging a regime "in the image and likeness" of the country, distinguished by a massive dose of rhetoric and theatricality (in addition to amorous intrigues) but with a low rate of violence and repression. In the representation of the twenty-year Fascist period the comparison with the Third Reich was used once again to mark the distance from the German experience and to paint a reassuring and benevolent picture of Fascism. The question of consensus was also read in this perspective. While in the 1970s De Felice had rightly criticised, on a historiographic level, the "antifascist paradigm" that made out that the entire Italian people had been oppressed by Fascism and was hostile to the regime, media revisionism in the 1980s imposed an opposite and no less misleading image: that of an Italian people wholly aligned with Fascism. ${ }^{32}$ This mass adherence to the dictatorship was presented as incontrovertible proof of the presumed merits of Fascism. Unlike the German debate, in which the issue of consensus for Nazism had created a problem of conscience and prompted a reckoning with the past, in Italy the discovery of consensus for the regime had paradoxically had a calming effect: the fact that so many Italians had subscribed to Fascism meant that the regime had not been so bad after all.

After the collapse of the so-called First Republic in the early 1990s, the arrival in power in 1994 and then in 2001 of the centre-right governments led by Berlusconi incentivised the spread of the revisionist reading of Fascism. ${ }^{33}$ It was in fact actively promoted through policies of memory, supported above all by Alleanza Nazionale, a political ally of Berlusconi and heir to the Movimento Sociale Italiano, the old neo-fascist party. These policies of memory had various fields of action. From when the first Berlusconi government took office in 1994 there was an intense cultural and legislative drive to place the combatants of Salò and the antifascist partisans on an equal footing, in the name of the good faith and ethical patriotism of those who chose to follow Mussolini in order to save, so it was affirmed, the honour of the nation. From the first decade of the new century onwards, centre-right local authorities took part in a nationwide drive to name streets, squares and public buildings after ex-Fascists, including high-ranking ones. At the same time, the centre-right political parties and governments made the paradigms of memory promoted by EU institutions their own. I am referring to the Shoah and the anti-to-

32 See P. Corner, "Fascismo e controllo sociale", Italia Contemporanea 228, 2002, pp. 381405; idem, "L'opinione popolare nell'Italia fascista degli anni trenta", [in:] Il consenso totalitario. Opinione pubblica e opinione popolare sotto fascismo, nazismo e comunismo, ed. P. Corner, Roma-Bari 2012, pp. 127-154.

33 See F. Focardi, “Il passato conteso...," pp. 59-70; A. Mattioli, “Viva Mussolini!”. La guerra della memoria nell'Italia di Berlusconi, Bossi e Fini, Milano 2011 (German first edition 2010). 
talitarian model that associates and condemns the crimes of communism and the crimes of Nazism. But how have these two pillars of memory been interpreted?

After the introduction in 2000 of the Day of Commemoration in Memory of the victims of the Shoah, the Italian right wing distinguished itself for its efforts to celebrate figures of good Italians who had saved Jews, especially ex-Fascists like Giorgio Perlasca or at any rate Fascist state officials like the police officer Giovanni Palatucci. ${ }^{34}$ They were presented as proof of the humanitarian face of Italian Fascism as opposed to the annihilating fury of the Germans. ${ }^{35}$ In 2004 the centre-right succeeded in securing the introduction of a memorial day to commemorate the Italian victims of the "foibe" and those expelled from Istria and Dalmatia, that is, Italians who fell victim after the war to violence perpetrated by Tito's communist regime in Yugoslavia. An anticommunist memory was thus counterposed to that of the antifascist Resistance. In public discourse, organs of information close to the centre-right governments, drawing on De Felice, argued that Italian Fascism had not been totalitarian in nature, as Nazism and communism had. So the heirs of the Italian Communist Party were the ones who were called upon to examine their consciences regarding their past. For the post-fascist Alleanza Nazionale right-wing the only black mark on Fascism had been the adoption of the racial laws against the Jews in $1938 .{ }^{36}$ In 1999 the secretary of Alleanza Nazionale, Gianfranco Fini, visited Auschwitz, and in 2002 publicly apologised to an Israeli newspaper for the anti-Semitic laws of Fascism. The year after, during a visit in Israel, Fini defined fascism as an "absolute evil" due its complicity in the Shoah. ${ }^{37}$ Having performed this act of purification, the mass media were once again pervaded by the benevolent image of Fascism in contrast to the demoniacal one of Nazism. Silvio Berlusconi also contributed to this. In an interview with the British newspaper "The Spectator" in 2003 he asserted: "Mussolini did not murder anyone. Mussolini used to send opponents on holiday in internal exile". 38

It is in this political and cultural context that the opinion survey regarding young Italians that we referred to at the beginning must be placed. In the year in which the survey was carried out, 2002, the historian Emilio Gentile, a former pupil of De Felice and one of the most prestigious international scholars of Fascism, warned against the spread in Italian public discourse of a "process of retroactive de-fascistisation" of Fascism, ${ }^{39}$ in other words, a tendency to rid the Fascist dictator-

34 See S.L. Sullam, I carnefici italiani. Scene dal genocidio degli ebrei (1943-1945), Milano 2015; E. Perra, "Legitimazing fascism trogh the Holocaust? The reception of the miniseries Perlasca: un eroe italiano in Italy", Memory Studies 3, 2010, pp. 95-109.

35 On the Italian memory culture of Holocaust see: R.S.C. Gordon, Scolpitelo nei cuori. L'Olocausto nella cultura italiana (1944-2010), Torino 2013 (English first edition 2012).

36 See S. Pivato, Vuoti di memoria. Usi e abusi della storia nella vita pubblica italiana, Roma-Bari 2007, p. 91.

37 See F. Focardi, La guerra della memoria..., pp. 70-71.

38 Ibid., p. 107.

39 See E. Gentile, Fascismo. Storia e interpretazione, Roma-Bari 2002, p. VII. 
ship of the liberticidal and criminal traits that it has historically displayed towards both internal opponents and towards the peoples attacked in Africa and Europe.

It was in relation to these aspects, to what we might call the dark pages of Fascism, that a new historiography began to develop precisely in the years of the revisionist tide, and which is still very active today. It cast a spotlight on the self-absolving myth of the "good Italian", revealing all the misdeeds of Fascist Italy: the colonial violence, the persecution of the Jews, the crimes committed in occupied territories during the Second World War. ${ }^{40}$ At the same time, in his books Gentile suggested that Fascism should be considered a totalitarianism just like Nazism and Stalin's communism. ${ }^{41}$ In his view, a model of totalitarianism does not exist, but rather a range of different "totalitarian laboratories", including Italian Fascism.

This historiographic work has struggled to make an impact on public discourse. Just consider that it was not until 2015 that the Italian state broadcasting service aired, on prime time, a history programme about Italian crimes in occupied Yugoslavia. ${ }^{42}$ Still, the revisionist tide is now for the most part on the ebb, at least as regards its most radical claims. For example, the request to equate by law the "young men of Salò" with the antifascist partisans has not been successful. But in Italian public opinion a widespread critical consciousness of Fascism is still absent. Indeed, the flawed comparison with Nazism is still prevalent. In Italy the "wicked German" continues to be a convenient alibi that represents an obstacle to a real reckoning with the country's Fascist past.

\section{Bibliography}

Baldassini, C. 2008. L'ombra di Mussolini. L'Italia moderata e la memoria del fascismo (19451960). Soveria Mannelli: Rubbettino.

Bandinelli, R.B. 1948. Dal diario di un borghese e altri scritti. Milano: Mondadori.

Bendiscioli, M. 1945. Neopaganesimo razzista. Brescia: Morcelliana.

Bonanate, L., Armao, F., \& Tuccari, F. 1997. Le relazioni internazionali. Cinque secoli di storia: 1521-1989. Milano: Bruno Mondadori.

Campi, A. 2001. Mussolini. Bologna: Il Mulino.

Collotti, E. 2003. Il fascismo e gli ebrei. Le leggi razziali in Italia. Roma-Bari: Laterza.

Conti, D. 2011. Criminali di guerra italiani. Accuse, processi e impunità nel secondo dopoguerra. Roma: Odradek.

Corner, P. 2002, "Fascismo e controllo sociale". Italia Contemporanea 228.

Corner, P. 2012. "L'opinione popolare nell'Italia fascista degli anni trenta". In: Il consenso totalitario. Opinione pubblica e opinione popolare sotto fascismo, nazismo e comunismo, ed. P. Corner. Roma-Bari: Laterza.

40 See F. Focardi, L. Klinkhammer, "Italia potenza occupante: una nuova frontiera storiografica", [in:] Politiche di occupazione dell'Italia fascista, Annale Irsifar, Milano 2006, pp. 21-30.

41 See first of all E. Gentile, La via italiana al totalitarismo...

42 I refer here to the programme D-Day-I giorni decisivi, directed by Tommaso Cerno and broadcast by RAI 3. 
Croce, B. 1944. Il dissidio spirituale della Germania con l'Europa. Bari: Laterza (now in: idem. 1963. Scritti e discorsi politici 1943-1947, vol. 1. Bari: Laterza).

Croce, B. 1963, "La libertà italiana nella libertà del mondo". In: idem, Scritti e discorsi politici 1943-1947, vol. 1. Bari: Laterza.

De Felice, R. 1961. Storia degli ebrei italiani sotto il fascismo. Torino: Einaudi.

Fargion, L.P. 2002. Il libro della memoria. Gli ebrei deportati dall'Italia (1943-1945). Milano: Mursia.

Focardi, F. 1999. "Alle origini di una grande rimozione. La questione dell'antisemitismo fascista nell'Italia dell'immediato dopoguerra". Horizonte. Italienische Zeitschrift für Kulturwissenschaft und Gegenwartsliteratur 4.

Focardi, F. 2005a. "Il vizio del confronto. L'immagine del fascismo e del nazismo in Italia e la difficoltà di fare i conti con il proprio passato". In: Italia e Germania 1945-2000. La costruzione dell'Europa, eds. G.E. Rusconi, H. Woller. Bologna: Il Mulino.

Focardi, F. 2005b. La guerra della memoria. La Resistenza nel dibattito politico italiano dal 1945 a oggi. Roma-Bari: Laterza.

Focardi, F. 2010. "Italy as occupier in the Balkans: Remembrance and war crimes after 1945". In: Experience and Memory. The Second World War, eds. J. Echternkamp, S. Martens. New York-Oxford: Berghahn Books.

Focardi, F. 2013a. Il cattivo tedesco e il bravo italiano. La rimozione delle colpe della seconda guerra mondiale. Bari-Roma: Laterza.

Focardi, F. 2013b. Il fascismo e la guerra dell'Asse. Una mancata resa dei conti. Padova: Imprimitur.

Focardi, F. 2013c. "Il passato conteso. Transizione politica e guerra della memoria in Italia dalla crisi della prima Repubblica ad oggi”. In: L'Europa e le sue memorie. Politiche e culture del ricordo dopo il 1989, eds. F. Focardi, B. Groppo. Roma: Viella.

Focardi, F. \& Klinkhammer, L. 2006. "Italia potenza occupante: una nuova frontiera storiografica". In: Politiche di occupazione dell'Italia fascista, Annale Irsifar. Milano: Angeli.

Fulvetti, G. \& Pezzino, P. 2016. Zone di guerra, geografie di sangue. L'Atlante delle stragi naziste e fasciste in Italia (1943-1945). Bologna: Il Mulino.

Galasso, G. 1998. "Benedetto Croce e l'unità europea". Nuova Storia Contemporanea 5.

Gentile, E. 2002. Fascismo. Storia e interpretazione. Roma-Bari: Laterza.

Gentile, E. 2003. Renzo De Felice: lo storico e il personaggio. Roma-Bari: Laterza.

Gentile, E. 2008. La via italiana al totalitarismo. Il partito e lo Stato nel regime fascista. Roma: Carocci.

Gerbi, S. \& Liucci, R. 2014. Indro Montanelli: una biografia (1909-2001). Milano: Hoepli.

Giovagnoli, A. 1991. La cultura democristiana. Roma-Bari: Laterza.

Gordon, R.S.C. 2013. Scolpitelo nei cuori. L'Olocausto nella cultura italiana (1944-2010). Torino: Bollati Boringhieri.

Il libro dei deportati, vol. 1. 2009. In: I deportati politici 1943-1945, eds. G. D’Amico, G. Villari, \& F. Cassata. Milano: Mursia.

Luporini, C. 1945. [about:] G. Ziemer, Educazione alla morte. Come si crea un nazista. Londra: Constable 1944. Società 3.

Luzzatto, S. 1998. Il corpo del duce. Torino: Einaudi.

Maritain, J. 1949. Umanesimo integrale. Roma: Studium.

Mattioli, A. 2011. "Viva Mussolini!'. La guerra della memoria nell'Italia di Berlusconi, Bossi e Fini. Milano: Garzanti.

Perra, E. 2010. "Legitimazing fascism trogh the Holocaust? The reception of the miniseries Perlasca: un eroe italiano in Italy". Memory Studies 3.

Pivato, S. 2007. Vuoti di memoria. Usi e abusi della storia nella vita pubblica italiana. Roma-Bari: Laterza.

Santomassimo, G. 2000. "Il ruolo di Renzo De Felice". In: Fascismo e antifascismo. Rimozioni, revisioni, negazioni, ed. E. Collotti. Roma-Bari: Laterza.

Studia nad Autorytaryzmem i Totalitaryzmem 40, nr 3, 2018

(C) for this edition by CNS 
Sarfatti, M. 2000. Gli ebrei nell'Italia fascista. Vicende, identità, persecuzione. Torino: Einaudi. Schwarz, G. 2004. Ritrovare se stessi. Gli ebrei nell'Italia postfascista. Roma-Bari: Laterza.

Sullam, S.L. 2015. I carnefici italiani. Scene dal genocidio degli ebrei (1943-1945). Milano: Feltrinelli.

Togliatti, P. 1979. "L'Italia e la guerra contro la Germania hitleriana". In: idem, Opere, eds. F. Andreucci \& P. Spriano, IV/2. Roma: Editori Riuniti.

Torchiani, F. 2016. Mario Bendiscioli e la cultura cattolica fra le due guerre. Brescia: Morcelliana.

\section{ITALY'S FASCIST PAST: A DIFFICULT RECKONING}

\section{Summary}

In January 2002, a survey conducted by a popular television program revealed that 25 percent of young Italians held a favorable opinion of Fascism and Dictator Benito Mussolini.

Shortly thereafter, Italy's most prominent scholar of Fascism, Emilio Gentile, warned of a "retroactive de-fascistization" in Italian society: the widespread tendency to cast fascism in a benevolent light forgetting, or softening, its repressive and brutal features.

For many Italians, Fascism was very different from Nazism and Communist Totalitarianism it might have been an authoritarian regime but it was not a bloody one. This assessment was no doubt further conditioned by the politics of memory promoted at that time by Silvio Berlusconi's center-right government.

However the origins of this watered-down interpretation go back much further. The idea that Italian Fascism was not on a par with other totalitarian regimes took root in the collective conscience following the end of World War II, as Italy attempted to rehabilitate its reputation in the eyes of the world, hoping to be spared harsh judgment and punishment on the international stage.

Its cornerstone was the contrast between Italian Fascism and German National Socialism. On one side, the brutality and ideological fanaticism of the Nazis and on the other, the Italian Fascists, who according to the narrative were over-bearing but not so criminal

This distinction between Fascism and Nazism has permeated Italian public opinion throughout the history of the Italian Republic. It was shared by historian Renzo De Felice and pervasive from the 1980s onward in mass media which were inspired by the new wave of revisionism.

Over the last twenty years, the 'dark pages' of Italian Fascism - from the regime's anti-Semitic policies to crimes committed in the colonies and Balkan territories occupied during the Second World War - have been thoroughly investigated in the historiography. Broad sectors of the public still however consider Fascism a mild dictatorship not without its merits. The country that invented Fascism, therefore, is still struggling to come to terms with the legacy of its Fascist past.

Keywords: memory of fascism, revisionism, good Italian/wicked German.

Filippo Focardi

filippo.focardi@unipd.it 